\title{
Obituary
}

\section{Harvey Reginald}

MacMillan, C.C., C.B.E.

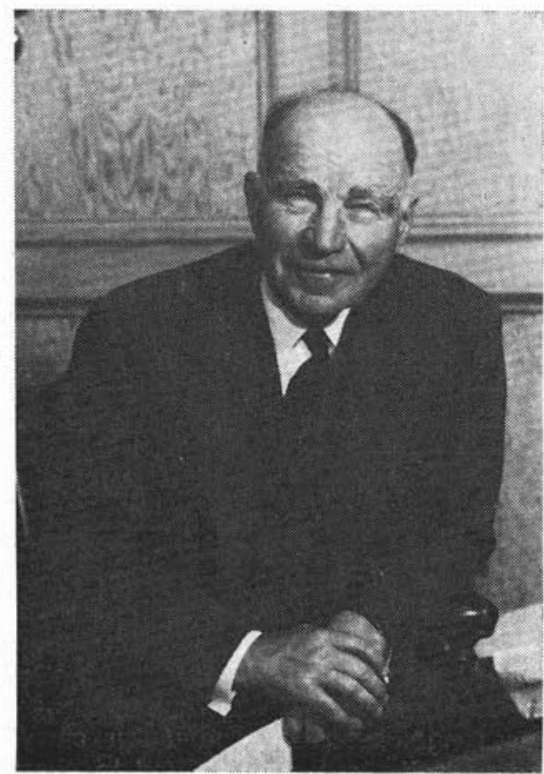

H. R. MacMillan, or "H. R." as he was affectionately known by many of his associates and friends, died on February 9, 1976, after celebrating his 90th birthday in the preceding September. He was born near Newmarket, now a suburb of Toronto, in 1885. At the age of 16 he completed high school, but being too young for university entrance, he was encouraged to enroll at the Ontario Agriculture College at Guelph, earning a degree in Agriculture. Subsequently he added Science at the University of Toronto, and then proceeded to Yale, graduating in 1908 with a Masters' degree in Forestry.

Following graduation he joined the Dominion Forestry branch of the Department of the Interior, Ottawa. In the fall of 1908, while working in the Rocky Mountain area of S. W. Alberta, he contracted a heavy cold which led to tuberculosis. A period of nearly three years of treatment and convalescence followed, leading eventually to recovery.

In 1911, H. R. became Assistant Director of Forestry in Ottawa and in June of the following year moved to B.C. where, at the age of 27, he became the first Chief Forester of the B.C. Forest Service.

Early in his career as Chief Forester he recognized that the province was grossly undercutting its resources and urged expansion. During the 1915-16 period he was on loan to the Federal Department of Trade and Industry and, as a Special Trade Commissioner, he travelled the world seeking markets.

When he returned to Victoria he resigned from the Forest Service to become Manager at the Victoria Lumber and Manufacturing Company's operation at Chemainus but soon left following differences of opinion over policy matters.

In the late war years he served as Assistant Director of the Aeronautical Supplies Department of the Imperial Munitions Board, charged with the task of expediting the production of Sitka spruce, mostly from the Queen Charlotte Islands.

At the end of the First World War he succeeded in putting into practice a recommendation made when, as Special Trade Commissioner, he had recognized the need for B.C. marketing of B.C. lumber. In 1919 , with a capital of less than $\$ 10,000$, he formed the H. R. MacMillan Export Company which initially acted as sales agent for B.C. mills.

The company succeeded beyond expectations and, after overcoming a freeze-out attempt in 1935, went on to continuing success in providing timber and converting facilities to supply both traditional and new markets.

In 1951 it merged with Bloedel, Stewart and Welch, an old established logging and lumber firm, to become MacMillan and Bloedel Ltd. which in 1959 merged with the Powell River Co. Ltd., a large newsprint producer. The new company, known as MacMillan Bloedel Limited, became the largest integrated forest products company in Canada and the Commonwealth. H. R. retired as President in 1951 and as Chairman of the Board in 1956, but remained a Director until 1970. 
Through the Second World War, H. R. worked as a dollar-ayear man for the Federal Government, under the overall direction of C. D. Howe, Minister of Munitions. He served first as Timber Controller, then as creator and head of the Wartime Requirements Board, charged with controlling and rationalizing arms and munitions programs of all kinds. Later he became President of Wartime Shipbuilding Ltd., a Crown corporation, when for a time Canada was the second largest cargo-ship-building country in the world and the organizational demands were staggering.

He made important submissions to two Royal Commissions of Forestry in B.C. - in 1945 and in 1956, both of which emphasized the need to maintain a place in the forest for the small independent loggers.

After giving up active management of MacMillan Bloedel he became a philanthropist with a special interest in education. It is estimated that his bequests to the University of British Columbia alone exceeded \$13 million. Other impressive gifts went to the Universities of Guelph and Carleton and to the United Church of Canada. Gifts of \$3.5 million to the City of Vancouver resulted in the building of a planetarium and the Hall of Tropical Fish in the Vancouver Aquarium. The U.B.C. library received his collection of old and rare books and Cathedral Grove on Vancouver Island was a 1944 bequest to the provincial government.

He received honorary degrees from U.B.C., Simon Fraser, Toronto, Guelph and Carleton Universities.

In his long career, H. R. was a forester, industrialist, capitalist (with some sympathy towards socialism), philanthropist, philosopher, and a great Canadian patriot. Newspapers have used many appellations to describe him - Lumber Giant, Lumber King, Timber Baron, Dean of Canadian Forestry, Benevolent Giant, and in his later years - a Living Legend. When he appeared as a witness before the second Sloan Commission, a news column was headed - "the King in Court". A Victoria columnist referred to H. R. as the Jolly Green Giant of Forestry.

H. R.'s achievements in the business world were the result of many qualities. He remained a hard worker throughout his long and active life. He had great ability in choosing capable managers, who then were given a large measure of responsibility. The Company's policy was expressed in the quote, "There are no Crown Princes in this Company - we train our managers". He had long vision and anticipated future events. Speaking of the Company, he was quoted on one occasion as saying, "We cannot afford to wait for things to happen, we must make them happen".

The Canadian Society of Forest Engineers, forerunner of the Canadian Institute of Forestry, was founded in 1908 following informal discussions of foresters in the Ottawa area and H. R. was active in the early years of the Society. Years later the latter was renamed the Canadian Institute of Forestry. In 1956 he was elected an Honorary Member of the CIF.

Dr. MacMillan is survived by his daughters, Mrs. Marion Lecky and Mrs. Jean Southam. His wife Edna, née Mulloy, of Aurora, Ont. died in 1962.

$$
\text { A. P. MacBean }
$$

[A condensation of Mr. MacBean's original sukmission. Ed.] 


\section{Canadian Institute of Forestry - Institut Forestier du Canada}

Incorporated 1950

Founded 1908

1975-76 National Officers

PRESIDENT: W. S. Moore, 703 Confederation Court, Thunder Bay "F", Ontario. P7E 3N2.

1st VICE PRESIDENT: A. B. Anderson, 2547 Ottawa Street, W. Vancouver, B.C. V7V $2 \mathrm{~T} 3$.

2nd VICE PRESIDENT: P. E. Boucher, 67 - 49th Avenue, Edmundston, N.B. E3V 3 E7.

PAST PRESIDENT: W. Young, 6401 Conconi Place, Victoria, B.C. V8Z $5 Z 7$.

EDITOR: J. D. MacArthur, Box 5000, Macdonald College, P.Q. HOA 1 CO.

MANAGER: A. G. Racey, Box 5000, Macdonald College, P.Q HOA 1 CO.

\section{Section Representatives on the Board of Directors}

ALGONQUIN: B. S. P. Wang, Petawawa Forest Experiment Station, Chalk River, Ont. KoJ 1 Jo.

CARIBOO: D. Wilson, 570 North Quinn St., Prince George, B.C. V2M 3J5.

CENTRAL ONTARIO: J. H. Sellers, Box 387, Sault Ste. Marie, Ontario. P6A 5M1.

CHAMPLAIN: H. Winer, FERIC, 245 Hymus Blvd., Pointe Claire, P.Q. H9R $1 \mathrm{G} 6$.

KOOTENAY: J. R. Cuthbert, 912 Kokanee St., Nelson, B.C. V1L 3P8.

LAKE OF THE WOODS: A. M. Van Fraassen, Dept. of Natural Resources, Dryden, Ont.

MANITOBA: G. A. Steneker, 501 University Cres., Winnipeg, Man. R3T 2 N6.

MARITIME: A. J. Kayll, Faculty of Forestry, University of New Brunswick, Fredericton, N.B. E3B 5A3. N.B.

NEWFOUNDLAND: J. A. Cook, Faculty Applied Science, Memorial University of Newfoundland, St. John's, Nfld. NORTHERN ONTARIO: Director to be named.

NORTHWESTERN ONTARIO: R. A. Baxter, 202 Kensington Dr., Thunder Bay "F", Ont. P7C 2 A5.

\section{SECTION OFFICERS}

\section{Chairman}

ALGONQUIN: C. W. Yeatman, Petawawa Forest Experiment Station, Chalk River, Ont. K0J 1 JO.

CARIBOO: R. W. Baker, 1021 François Crescent, Prince George, B.C.

CENTRAL ONTARIO: B. J. Stocks, Box 387, Sault Ste. Marie, Ontario. P6A 5M1.

CHAMPLAIN: H. Winer, FERIC, 245 Hymus Blvd., Pointe Claire, P.Q. P6A 5M1.

KOOTENAY: J. K. Robertson, Box 611, Nakusp, B.C. VO6 1 R0.

LAKE OF THE WOODS: Wm. Kuzemchuck, P.O. Box 881 , Sioux Lookout, Ont. POV 2TO.

MANITOBA: R. H. Lamont, 1447 Somerville Ave., Winnipeg, Man. R3T 1 C4.

MARITIME: H. Oldham, Maritime Forest Research Centre, CFS, Box 4000, Fredericton, N.B.

NEWFOUNDLAND: K. J. S. Beanlands, 7 Winnipeg St., St. John's, Nfld. A1A $2 R 1$.

NORTHERN ONTARIO: V. I. Sleep, 113 Riverside Drive, Kapuskasing, Ont. P5N 1 B4.

NORTHWESTERN ONTARIO: Gary R. Bloomfield, 524 E. Christena St., Thunder Bay ' $F$ ', Ont. P7E 4P2.

NOVA SCOTIA: H. T. Routledge, Woodlands Dept., N.S. Pulp Ltd., Port Hawkesbury, N.S. BOE 2V0.

OKANAGAN: I. S. Tolnai, Weyerhaeuser Canada Ltd., Box 800 , Kamloops, B.C. V2C $5 \mathrm{M} 7$.

ORLEANS: J. G. Davidson, C.P. 367, 4040 rue des Cedres, Cap-Rouge, P.Q. GOA 1 KO.

OTTAWA VALLEY: J. R. Clements, P.O. Box 231, Munster, Ont.

PACIFIC: W. Dumont, Box 4000, Port Alice, B.C.

ROCKY MOUNTAIN: R. E. Stevenson, Northern Forest Re-

ROCKY MOUNTAIN: J. A. Beck, Jr., Dept. of Forest Science, University of Alberta, Edmonton, Alberta.

timi, P.Q. G7H 5B6.

SASKATCHEWAN: M. T. Little, Dept. of Tourism \& Ren. Res., Forestry Branch, Provincial Office Bldg., Prince Albert, Sask. S6V 1B5.

SOUTHERN ONTARIO: S. N. Linzon, Supervisor Phytotoxicology Section, Air Resources Branch, 880 Bay St., Toronto, Ont. M5S' $1 \mathrm{Z8}$.

VANCOUVER: J. Toovey, 2976 Williams Ave., N. Vancouver, B.C. V7K $1 Z 6$.

VANCOUVER ISLAND: J. T. Arnott, 647 St. Patrick Street, Victoria, B.C. V8S $4 \times 4$.
NOVA SCOTIA: G. B. Lapointe, c/o N. S. Pulp Ltd., P.O. Box 59, Port Hawkesbury, N.S. BOE 2V0.

OKANAGAN: To be named.

ORLEANS: M. R. Roberge, Canadian Forestry Service, Box 3800 Ste. Foy P.0 G1V 4C7.

OTTAWA VALLEY: H. A. Peacock, Dept. of Indian Affairs and Northern Devel., 400 Laurier St., Centennial Towers, Ottawa, Ont. K1A OH4.

PACIFIC: R. Lasser, Box 220, Gold River, B.C.

ROCKY MOUNTAIN: J. I. Johnston, Box 306, Grande Prairie, Alta. T8V 3 A5.

SAGUENAY: Rémy-N. Ouellet, The Price Co., Chicoutimi. P.Q. G7H $5 B 6$.

SASKATCHEWAN: Keith Gorham, 608 - 20th Street W. Prince Albert, Sask. S6V $4 \mathrm{H} 3$.

SOUTHERN ONTARIO: V. G. Smith, 508 Riverside $\mathrm{Dr}$. Toronto, Ont. M6S 4B5.

VANCOUVER: L. G. Kenwood, Reid, Collins \& Assoc. Ltd. Forest Industries Bldg., 550 Burrard St., Vancouver, B.C. V6C 2 K6

VANCOUVER ISLAND: C. P. Brett, 3163 Stevenson Place, Victoria, B.C. V8X $1 \mathrm{C} 4$.

\section{Secretary}

ALGONOUIN: A. B. Berry, Petawawa Forest Experiment Station, Chalk River, Ont. K0J 1J0.

CARIBOO: F. J. Lowenberger, c/o Industrial Forestry Service \#101 - 1595 Fifth Ave., Prince George, B.C. V2L 3L9

CENTRAL ONTARIO: G. D. Huntley, Box 387, Sault Ste. Marie, Ont. P6A 5M1.

CHAMPLIAN: E. Heidersdorf, FERIC, 245 Hymus Blvd., Pointe Claire, P.Q. H9R 1G6.

KOOTENAY: D. Parminter, 518 Lake Street, Nelson, B.C. V1L 4C6.

LAKE OF THE WOODS: B. A. Ferguson, 834 Minnie Ave., Fort Francis, Ont. P9A 2R1.

MANITOBA: N. B. Tuinhof, 31 Hammond Rd., Winnipeg, Man. R3R 1L9.

MARITIME: H. E. O'Brien, 115 Gorham Drive, Nashwaaksis N.B. E3A $2 A 8$.

NEWFOUNDLAND: S. E. Holmes, P.O. Box 359, Manuels, Nfld AOA $2 Y 0$.

NORTHERN ONTARIO: R. G. Lightheart, 9 Maple Drive, Kapuskasing, Ont.

NORTHWESTERN ONTARIO: Herb Bax, 310 S. Hill St., Thunder Bay "N", Ont. P7B 3V8.

NOVA SCOTIA: C. A. Steel, Box 607, 27 Stoneybrook Court, Stoneybrook Manor, Halifax, N.S.

OKANAGAN: R. G. Jennejohn, c/o District Forester, B.C Forest Service, Kamloops, B.C. V2C 2T7.

ORLEANS: Gilles Frisque, Centre Rech. For. Laurentides, C.P. 3800,1080 du Vallon, Ste. Foy, P.Q. G1V 4C7.

OTTAWA VAlLEY: E. Stechishen, Box 893, Manotick, Ont. KOA 2 NO.

PACIFIC: D. Haley, Box 543, Port McNeill, B.C.

ROCKY MOUNTAIN: W. D. Johnstone, Northern Forest Research Centre, 5320 - 122nd St., Edmonton, Alta. T6H $3 S 5$

SAGUENAY: H. W. Journeaux, 306 Foucault Ave., Arvida, P.Q. G7S 2L2.

SASKATCHEWAN: H. S. Price, 359 - 21st Street West, Prince Albert, Sask. S6V 4J2.

SOUTHERN ONTARIO: Wm. D. Baker, 328 The West Mall, Apt. 307, Etobicoke, Ont. M9G 1 G8.

VANCOUVER: K. P. Campbell, 675 Burley Drive, West Vancouver, B.C. V7T $1 Z 3$.

VANCOUVER ISLAND: Eleanor E. McMullan, PFRC, 506 West Burnside Road, Victoria, B.C. V8Z 1 M5. 